\title{
Higher abundance and diversity in faunal assemblages with the invasion of Codium fragile ssp. fragile in eelgrass meadows
}

\author{
Annick Drouin ${ }^{1,2, *}$, Christopher W. McKindsey ${ }^{1}{ }^{,}$Ladd E. Johnson ${ }^{2}$ \\ ${ }^{1}$ Ocean and Environmental Sciences Division, Maurice-Lamontagne Institute, Fisheries and Oceans Canada, PO Box 1000, \\ Mont Joli, Québec G5H 3Z4, Canada \\ ${ }^{2}$ Département de biologie et Québec-Océan, Université Laval, Québec, Québec G1V 0A6, Canada
}

\begin{abstract}
The present study examined how species-specific attributes of the invasive alga Codium fragile ssp. fragile (hereafter Codium) and eelgrass Zostera marina influenced faunal assemblages associated with eelgrass ecosystems in îles de la Madeleine, eastern Canada. Direct association of species with Codium $(<1 \mathrm{~m})$ was evaluated and compared to eelgrass faunal assemblages from invaded beds. Potential neighborhood effects (ca. $10 \mathrm{~m}$ ) were assessed by comparing invertebrates associated with eelgrass in invaded and non-invaded beds. The influence of Codium on more mobile species was evaluated by comparing fish assemblages associated with macrophytes in invaded and non-invaded beds. In addition, species-area relationships for low mobility species associated with Codium were contrasted between beds where Codium or eelgrass was the dominant structuring macrophyte. Codium had distinct invertebrate species assemblages, as there was a greater abundance and diversity of invertebrates associated with Codium than with eelgrass, and multivariate assemblage structure differed between macrophyte types. In contrast, no neighborhood patterns were observed as invertebrate assemblages associated with eelgrass did not differ between invaded and non-invaded beds, suggesting that the mechanisms that account for differences between the invertebrate assemblages are a function of the macrophyte's nature and operate at small spatial scales. Fish community structure differed between invaded and non-invaded beds, largely due to a greater abundance of 2 fishes, Apeltes quadracus and Tautogolabrus adspersus, in invaded beds. Epifaunal abundance and species richness were positively correlated with Codium thallus biomass, and the abundance relative to biomass correlation was greatest where Codium was the dominant macrophyte. Experimental manipulation of thallus structure to create straight or branched Codium fronds with similar surface area showed that associated invertebrate and gastropod abundance was not influenced by this factor and indicated that factors other than macrostructure complexity influenced the presence of epifauna on the introduced alga. Overall, the present study suggests that the invasion of eelgrass beds by Codium increases faunal density and diversity. However, longer-term effects of Codium invasion in this and other eelgrass ecosystems require further assessment, as the severity of the invasion effects on faunal communities likely depends on the interaction between Codium and eelgrass.
\end{abstract}

KEY WORDS: Codium fragile $\cdot$ Exotic macroalgae $\cdot$ Eelgrass $\cdot$ Zostera marina $\cdot$ Diversity $\cdot$ Invasive species impacts

Resale or republication not permitted without written consent of the publisher

\section{INTRODUCTION}

Together with habitat destruction, climate change, and overharvesting, invasive species are among those factors with the greatest perceived impacts on biodi- versity in coastal areas (Lotze et al. 2006, Williams \& Grosholz 2008). Macroalgae constitute a significant part of the exotic marine flora, with 277 introduced species worldwide (Williams \& Smith 2007). Exotic macroalgae have been reported to impact native 
biota by competing with native macrophytes and influencing the abundance and diversity of associated fauna (see review by Schaffelke \& Hewitt 2007). However, empirical evidence of impacts and experiments on the potential mechanisms causing changes remain scarce. Effects have been reported for only $6 \%$ (Williams \& Smith 2007) and experimentally tested for only $2.1 \%$ (Thomsen et al. 2009) of exotic macroalgal species.

Habitat-forming species, such as macrophytes, influence the diversity and distribution of faunal assemblages by modifying physical and biological conditions (Crooks 2002, Bruno et al. 2003). The ecological function of different macrophytes can be similar as they are primary producers that provide physical habitat and trophic support to other species. However, speciesspecific attributes with respect to the phenology, morphology and biology of different species can influence the structure of associated communities through a number of mechanisms (Wernberg et al. 2000, Bégin et al. 2004, York et al. 2006). Increased cover or density can limit movement and foraging activities of mobile species (Nordström \& Booth 2007) and provide hiding opportunities for potential prey. Species morphology can directly influence habitat properties by providing microhabitats needed for different taxa (Christie et al. 2007) or indirectly influence recruitment through passive (e.g. hydrodynamics deposition) or active (e.g. habitat selection) means or affect post-recruitment survival by offering refuge against visual predators (Connolly 1994). Macrophytes may also differ in texture, palatability and energetic content (Lyons \& Scheibling 2007).

In its native and introduced range, the green macroalga Codium fragile ssp. fragile (formerly $C$. fragile ssp. tomentosoides; Provan et al. 2008), hereafter Codium, is usually associated with hard substrata habitat. However, in the southern Gulf of St. Lawrence, eastern Canada, where Codium has recently established (Lyons \& Scheibling 2009), this alga demonstrates great ecological plasticity such that it can also settle and grow on eelgrass rhizomes, allowing it to successfully establish populations in soft-sediment habitats (Garbary et al. 2004). High densities of Codium were found in eelgrass Zostera marina beds in îles de la Madeleine, southern Gulf of St. Lawrence, in 2003 (Simard et al. 2007), and Codium has since persisted and expanded.

To date, studies on the impacts of Codium on local assemblages of the Northwest Atlantic have been limited to rocky shores, although it may also affect eelgrass communities. In rocky systems, Codium is a preemptive species that may colonize bare substrata and prevent re-colonization of native canopy-forming species (Malinowski \& Ramus 1973, Scheibling \& Gagnon
2006). Codium can modify communities by increasing the diversity of epibionts (Harris \& Jones 2005, Schmidt \& Scheibling 2006) and altering the composition of turf algae (Schmidt \& Scheibling 2007). Other specific interactions have also been reported. Not surprisingly, when herbivores specializing on Codium such as the sacoglossid opisthobranchs Placida dendritica and Elysia viridis (Trowbridge 1998, Harris \& Jones 2005) are present, Codium has a positive effect on their abundance. Conversely, the abundance of the generalist snail Lacuna vincta is decreased in habitats dominated by Codium and individual $L$. vincta that were fed on Codium were smaller than those that were fed a normal diet (Chavanich \& Harris 2004). A manipulative study demonstrated lower recruitment of a fish (cunner Tautogalabrus adspersus) to Codium than to native kelp beds (Levin et al. 2002).

We first examined whether Codium has a distinct species association and compared invertebrate communities directly associated with Codium to those associated with eelgrass. To evaluate the generality of observations, we did this at multiple spatial scales ranging from replicates separated by ca. $1 \mathrm{~m}$ within areas separated by ca. $10 \mathrm{~m}$ within a given meadow to among meadows separated by ca. $200 \mathrm{~m}$ within each of 2 bays separated by ca. $5 \mathrm{~km}$. Second, we evaluated whether Codium had a neighborhood effect on eelgrass-associated invertebrate fauna by comparing invertebrate assemblages in eelgrass areas within Codium-dominated meadows to invertebrate assemblages in eelgrass areas within meadows in which Codium is nearly absent. Third, we evaluated whether Codium influenced assemblages of more mobile species by comparing fish assemblages between invaded and non-invaded meadows. Fourth, we assessed the influence of Codium thalli characteristics (biomass, length, bushiness index) on invertebrate assemblages and the effect of the surrounding habitat on species accumulation by examining the correlation between invertebrate assemblage parameters and Codium thalli characteristics from eelgrass meadows dominated by Codium and another where Codium was rare. Finally, we did an in situ manipulative experiment to evaluate whether Codium morphology influenced the invertebrates associated with the alga.

\section{MATERIALS AND METHODS}

Study site. The study was conducted in eelgrass beds in Great-Entry Lagoon, îles de la Madeleine, eastern Canada $\left(47^{\circ} 37^{\prime} \mathrm{N}, 61^{\circ} 31^{\prime} \mathrm{W}\right.$, Fig. 1). This region is characterised by low tidal amplitude $(0.60 \mathrm{~m})$ with a stable average salinity in the lagoon of around $30 \%$ as precipitation is the only source of fresh water. Water 


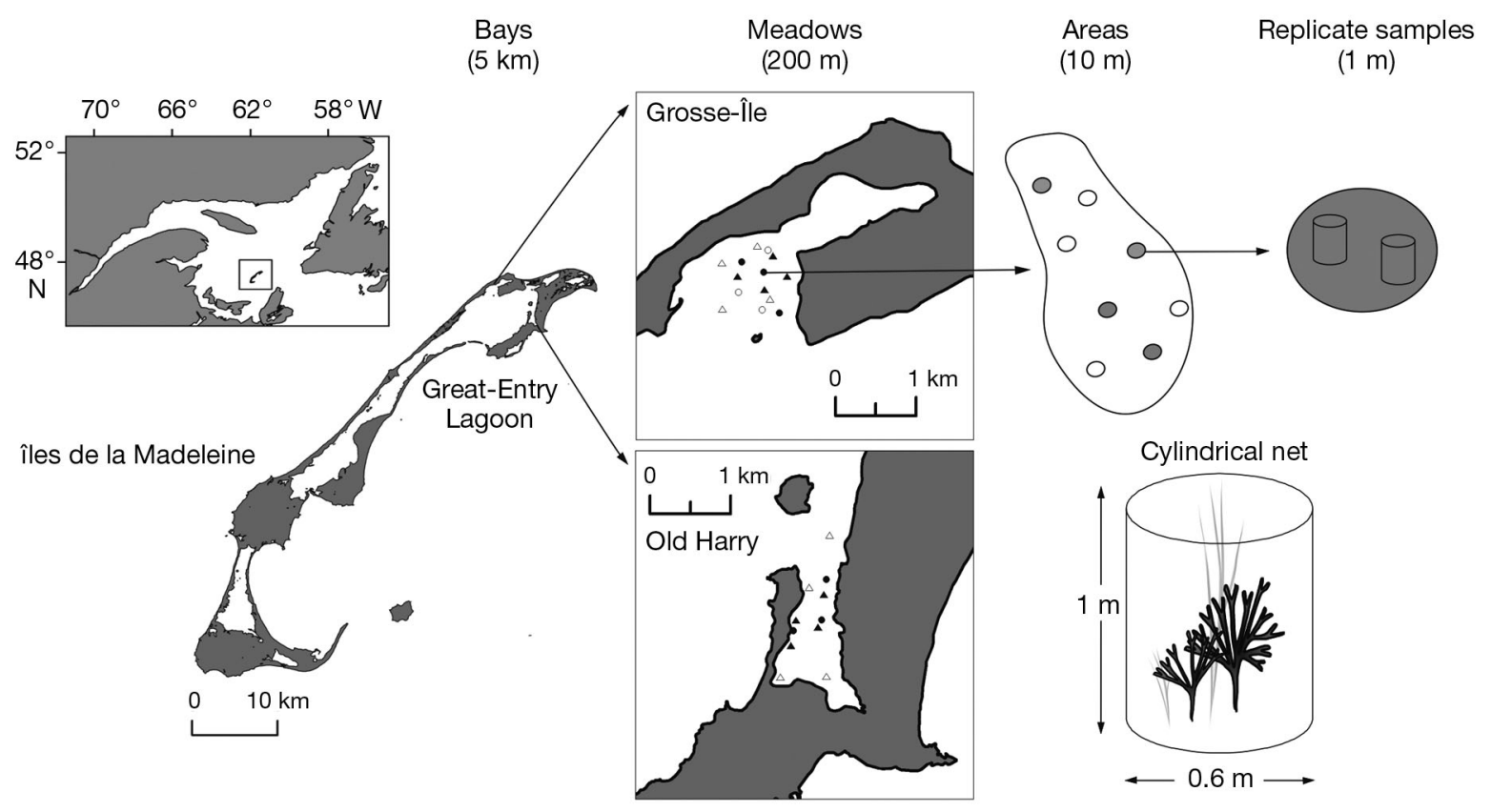

Fig. 1. Location of the study sites in Great-Entry Lagoon, îles de la Madeleine, eastern Canada, and the spatial scales at which variation in assemblages were evaluated. Circles correspond to locations where fish were sampled in invaded (black) and noninvaded (white) beds. Triangles correspond to locations where invertebrates were sampled in invaded (black) and non-invaded (white) beds. The invertebrate sampling design is illustrated, where circles represent areas of Codium (grey) and eelgrass (white) within a sampled invaded bed

temperature can exceed $20^{\circ} \mathrm{C}$ in summer and decrease below $0^{\circ} \mathrm{C}$ during the winter (December to April). Codium was first observed in this area in 2003 growing on rhizomes although the extent of the population indicated that it was already well established (Simard et al. 2007) and suggested that it had been present for at least 3 to $5 \mathrm{yr}$. Like eelgrass, Codium is perennial in this region, although bleaching events during winter time and dislodgment by currents and ice can cause local fluctuation in algal biomass throughout the year (A. Drouin pers. obs.). At the time of sampling, eelgrass was the main macrophyte in the lagoon. When present, the distribution of Codium in eelgrass beds was patchy, with densities varying at different spatial scales such that relatively monospecific eelgrass areas were interspersed with areas (often $>25 \mathrm{~m}^{2}$ ) largely dominated by Codium ( $>75 \%$ cover). Eelgrass and Codium cover were evaluated using 20 randomly placed $50 \times 50 \mathrm{~cm}^{2}$ quadrats (each subdivided into 100 squares) at each of 8 sites where Codium was visually abundant and at 8 sites where it was rare or absent (black and white triangles in Fig. 1, respectively). In all cases, invaded beds refer to sites where mean $( \pm \mathrm{SD})$ eelgrass cover was $49.6 \pm 32.4 \%$ and mean Codium cover was $47.0 \pm$ $22.3 \%$ and non-invaded beds refer to sites where the mean eelgrass cover was $91.1 \pm 19.8 \%$, with scarce drift Codium fragments present in half of the non- invaded sites, representing $2.8 \pm 11.9 \%$ cover. All sampling for the mensurative part of this study was performed in ca. $1 \mathrm{~m}$ deep water at low tide between July 21 and 26, 2006.

Invertebrate assemblages. Epifaunal invertebrate samples were collected, using SCUBA, with a cylindrical net of $1 \mathrm{~mm}$ mesh with a $0.28 \mathrm{~m}^{2}$ footprint (Fig. 1). The net was slowly lowered on the canopy and then the base of the algae/plants cut with a pair of grass shears and the bottom of the net quickly closed to collect all of the associated fauna. Thus samples included all the organisms $>1 \mathrm{~mm}$ associated with the thallus/ leaves as well as epibenthic organisms under the canopy. Organisms were preserved in $10 \%$ formalin, identified to the lowest taxonomic level possible in the laboratory, and counted.

The direct association of organisms with Codium (i.e. $<1 \mathrm{~m}$ ) and eelgrass was evaluated by sampling invertebrates following a hierarchical sampling design to ensure the generality of the observations at several spatial scales and reflect the patchy nature of Codium within the eelgrass habitat (Fig. 1). Two replicate macrophyte samples, separated by ca. $1 \mathrm{~m}$, were collected in each of 4 Codium areas and 4 eelgrass areas (Macrophyte) separated by ca. $10 \mathrm{~m}$ within each of 3 invaded beds (Bed). An 'Area' was defined as a sampling location where one or the other species com- 
prised the majority, i.e. $>95 \%$, of the canopy biomass within a given $10 \mathrm{~m}^{2}$ area. Areas were separated by ca. $10 \mathrm{~m}$ and beds by ca. $200 \mathrm{~m}$. Sampling was done in each of 2 embayments, Old Harry $(\mathrm{OH})$ and Grosse-île (GI), which were separated by ca. $5 \mathrm{~km}$ (Bay), for a total of 96 samples.

The presence of neighborhood effects (ca. $10 \mathrm{~m}$ scale) by Codium on eelgrass-associated invertebrates was evaluated by comparing invertebrate assemblages within eelgrass areas in invaded beds to those in eelgrass areas in non-invaded beds that were sampled following the same sampling design as for the Codiumeelgrass comparison. Sampling for this comparison was only done in GI, yielding a total of 48 samples.

Fish assemblages. Fish were sampled during the day using a $15 \mathrm{~m}$ wide beach seine with a $1.2 \times 1.2 \times$ $1.2 \mathrm{~m}^{3}$ central pocket and $5 \mathrm{~mm}$ mesh size. The seine was deployed by 2 people who extended the net to its maximum length and then closed the 2 ends, giving a sampling area of approximately $88 \mathrm{~m}^{2}$. A third person then hauled the net into a small boat and emptied the contents of the central pocket into pans that were subsequently sorted in the field before being frozen. Three replicate samples, separated by ca. $20 \mathrm{~m}$, were taken in each of 4 invaded and 4 non-invaded beds, separated by ca. $200 \mathrm{~m}$ (Bed nested in Bed type) in each of $\mathrm{OH}$ and GI (Bay). Water depth was measured near the boat after each fish catch and was $1.00 \pm$ $0.15 \mathrm{~m}( \pm \mathrm{SD})$ for all sites. All fish caught were counted, identified, and total length measured, in the laboratory.

Invertebrate-algal relationships. The relationship between invertebrate abundance and richness and the size and complexity of Codium fronds was examined by randomly sampling thalli of different sizes in an invaded bed where Codium was the dominant macrophyte (i.e. $>75 \%$ cover) and an invaded bed where the presence of Codium was sparser (i.e. $<15 \%$ cover). The length and circumference of each thallus was measured in situ, using SCUBA, and a 'bushiness index' was calculated as an indicator of thallus complexity (Bégin \& Scheibling 2003). Each Codium specimen was then covered with a plastic bag and manually removed from the substratum. Thus only organisms associated with the Codium thallus were sampled. Organisms were removed by rinsing individual thalli over a sieve with $1 \mathrm{~mm}$ mesh. The fresh weight (i.e. biomass) of each thallus was then measured after removing excess water with a salad spinner.

Algal manipulations. One mechanism that may explain observed variation in the relationship between species abundance/richness and algal size is the role of thallus morphology ('complexity', sensu Dean \& Connell 1987a). To test this hypothesis, we manipulated Codium thallus morphology to yield branched or straight Codium thalli with similar surface areas and compared the colonization by invertebrates to these structures in 2008. Codium thalli were collected at one site in $\mathrm{OH}$, transported to the lab, and defaunated by rinsing them with fresh water. Branched forms were obtained by cutting off ramifications, preserving only 16 dichotomies per alga whereas straighter forms were obtained by cutting off the entire ramification and keeping only the 2 main branches forming a ' $\mathrm{V}$ '. Five ' $\mathrm{V}$ ' branches were used to create a straight form of comparable surface area with the branched structures. Each form was inserted in a small transparent cylindrical plastic tube (about $1.5 \mathrm{~cm}$ wide and $1.5 \mathrm{~cm}$ long) attached to a $25-\mathrm{cm}$-long aluminum stake which was used to anchor it in the sediment.

Ten manipulated algae of each Codium morphology were installed randomly at an eelgrass site with $<25 \%$ Codium cover in $\mathrm{OH}\left(47^{\circ} 34^{\prime} 50.91^{\prime \prime} \mathrm{N}, 61^{\circ} 29^{\prime} 37.83^{\prime \prime} \mathrm{W}\right)$ such that each experimental alga was separated from another by $>10 \mathrm{~m}$. All structures were installed on July 30 , and, to test the hypothesis that accumulation of sediments or epiphytes on the fronds influences the associated assemblages, half of them $(n=5$ per morphology) were removed after $2 \mathrm{wk}$ (sampled August 13 to 14) and the other half after 9 wk (sampled October 10). The invertebrates associated with each alga were sampled by slowly lowering a plastic bag over a thallus, tightening the bag near the bottom, and then removing the thallus from the sediment. At both sampling times, non-manipulated Codium and eelgrass were similarly sampled using the same method as that for manipulated algae to compare the invertebrate assemblages that had colonized the manipulated algae to natural assemblages. Although the anchoring devices were assumed to have negligible effects on the colonization of the thalli, care was taken to not include any organisms associated with them. All invertebrates $>1 \mathrm{~mm}$ associated with thallus/leaves were collected, preserved in $10 \%$ formalin, identified to the lowest taxonomic level possible in the laboratory, and counted. The wet-weight biomass of each Codium or eelgrass specimen was measured as above.

To standardize the number of organisms per surface area of Codium and eelgrass, the biomass versus surface area relationship was determined for both macrophytes. The surface area of 20 Codium thalli (biomass from 12 to $144 \mathrm{~g}$ ) was assessed geometrically by assuming that each segment was a cylinder (i.e. Codium surface area $=\Pi \times$ diameter $\times$ length). The surface area of 30 eelgrass shoots (biomass from 0.13 to $3.24 \mathrm{~g}$ ) was also assessed geometrically by assuming each leaf was a simple rectangle with 2 surfaces (i.e. eelgrass leaf surface $=$ length $\times$ width $\times 2$ ).

Statistical analyses. Species abundance, community characteristics (species richness $S$, evenness index $J^{\prime}$, 
and Shannon diversity index $H^{\prime}$ ) and fish length were compared among habitats and spatial scales using ANOVA. Assumptions of normality and homoscedasticity were evaluated by visual inspection of the distribution of residuals to predicted values (Quinn \& Keough 2002). Data were transformed where necessary to satisfy the assumptions of ANOVA (see 'Results' for details). A posteriori comparisons were done using Tukey's tests.

Multivariate species assemblages were compared using permutational multivariate analysis of variance (PERMANOVA, Anderson 2001, McArdle \& Anderson 2001) based on Bray-Curtis dissimilarity distances calculated from square-root transformed data using PRIMER 6 and PERMANOVA+, except for the manipulative experiment. Experimental Codium thalli varied in size and this may influence species richness in a non-linear manner, potentially creating a sampling artefact on richness. Thus, invertebrate assemblage structure among treatments was compared using raw abundance data (ind. $\mathrm{cm}^{-2}$ ) to reduce the influence of richness in species assemblages in the multivariate analyses (Clarke \& Warwick 2001). Species that contributed the most to discriminating among assemblages were identified using SIMPER (Clarke 1993). Variation among species assemblages is shown graphically using non-metric, multi-dimensional scaling (MDS) and cluster analysis to identify samples that grouped together. To facilitate visualisation, MDS ordinations for the mensurative experiments show centroids calculated as the distance between replicates for the factors Bed and Macrophyte for invertebrate assemblages and for Bed type for fish samples.

Although the aim of this study was to identify generalities with respect to the spatial structure of the influence of Codium on eelgrass meadow communities, at the time of sampling, Codium was found at high densities in only 2 bays in îles de la Madeleine, both of which were included in the study. As all levels possible with respect to this spatial scale were sampled, we interpret this factor as fixed and thus limit the inference of the factor Bays to these 2 levels (see Underwood 1981). Three samples of invertebrates associated with eelgrass in Codium meadows were inadvertently mixed during laboratory manipulations and were omitted from all analyses ( 1 from $\mathrm{OH}$ and 2 from GI). One replicate of dichotomous Codium was missing at the end of the experiment.

The relationships between assemblage measures (abundance and species richness), Codium size (biomass, length, and bushiness index), and sample locations (Codium-dominated or eelgrass-dominated meadow) were evaluated using ANCOVA and linear regression.

\section{RESULTS}

\section{Invertebrate assemblages}

A total of 85 invertebrate taxa were identified within the following groups: crustacea (9 amphipods, 4 decapods, 3 isopods, 1 cumacean), echinodermata (2 asteroideans), mollusca (8 bivalves, 14 gastropods) and polychaeta (44, from 18 families). Most taxa were identified to the species level (69 to species, 7 to genus, and 9 to family). All assemblages were dominated by gastropods, which accounted for nearly $75 \%$ of the total number of individuals in canopies, followed by amphipods, which accounted for $>10 \%$.

Overall, community characteristics varied spatially between beds and areas within beds, but similar patterns were observed in the 2 bays. Total abundance, species richness $(S)$, and Shannon diversity $\left(H^{\prime}\right)$ were greater in Codium than in eelgrass samples although the magnitude of differences between the 2 macrophytes was greater in $\mathrm{OH}$ (Table 1, Fig. 2). Greater $H^{\prime}$ in Codium replicates seems to be associated with greater $S$ rather than a more equal proportion of individuals among the species, as evenness $\left(J^{\prime}\right)$ did not vary significantly with macrophyte type (Table 1, Fig. 2).

Invertebrate species assemblages differed between Codium and eelgrass samples (Table 2). Although assemblage structure differed among beds, samples from Codium were consistently distinct from those from eelgrass (Table 2). MDS shows that eelgrass and Codium samples collected in the same invaded bed form distinct clusters and generally differ in a similar way (i.e. paired centroids are typically dispersed in the same direction in Fig. 3), as is indicated by the non-significance of the MA $\times \mathrm{BE}(\mathrm{BA})$ interaction (Table 2). Gastropods, specifically Onoba aculeus, Littorina saxatilis, Alvania sp., and Hydrobia sp., and, to a lesser extent the amphipod Corophium sp., contributed most to the dissimilarity in community structure between Codium and eelgrass (Table 3 ). All these species were more abundant when associated with Codium (log (Onoba aculeus +1$) F_{1,4}=13.26, \mathrm{p}=0.022 ; \log$ (Alvania sp. +1$) F_{1,4}=18.17, \mathrm{p}=0.013 ; \log ($ Hydrobia sp. +1$)$ $F_{1,4}=22.59, \mathrm{p}=0.009 ; \log$ (Corophium sp. +1$) F_{1,4}=$ 22.77, $\mathrm{p}=0.009$ ), with the exception of L. saxatilis, which did not differ significantly between macrophyte types $\left(F_{1,4}=2.91, \mathrm{p}=0.163\right)$. The variability of the presence or the abundance of $L$. saxatilis in Codium replicates may explain the contribution of this species to the dissimilarity in community structure between the 2 macrophyte types.

Invertebrate assemblages in eelgrass from invaded beds did not differ from those in non-invaded beds with respect to total abundance, $S, J^{\prime}$, or $H^{\prime}$ (Table 1 , 
Table 1. ANOVA results for the influence of macrophyte type (MA: Codium or eelgrass) or bed composition (CO: invaded or noninvaded) on invertebrate and fish assemblage characteristics in multiple areas (AR), beds (BE), and/or bays (BA). MA, CO and BA are fixed factors. Values in bold indicate statistically significant effects

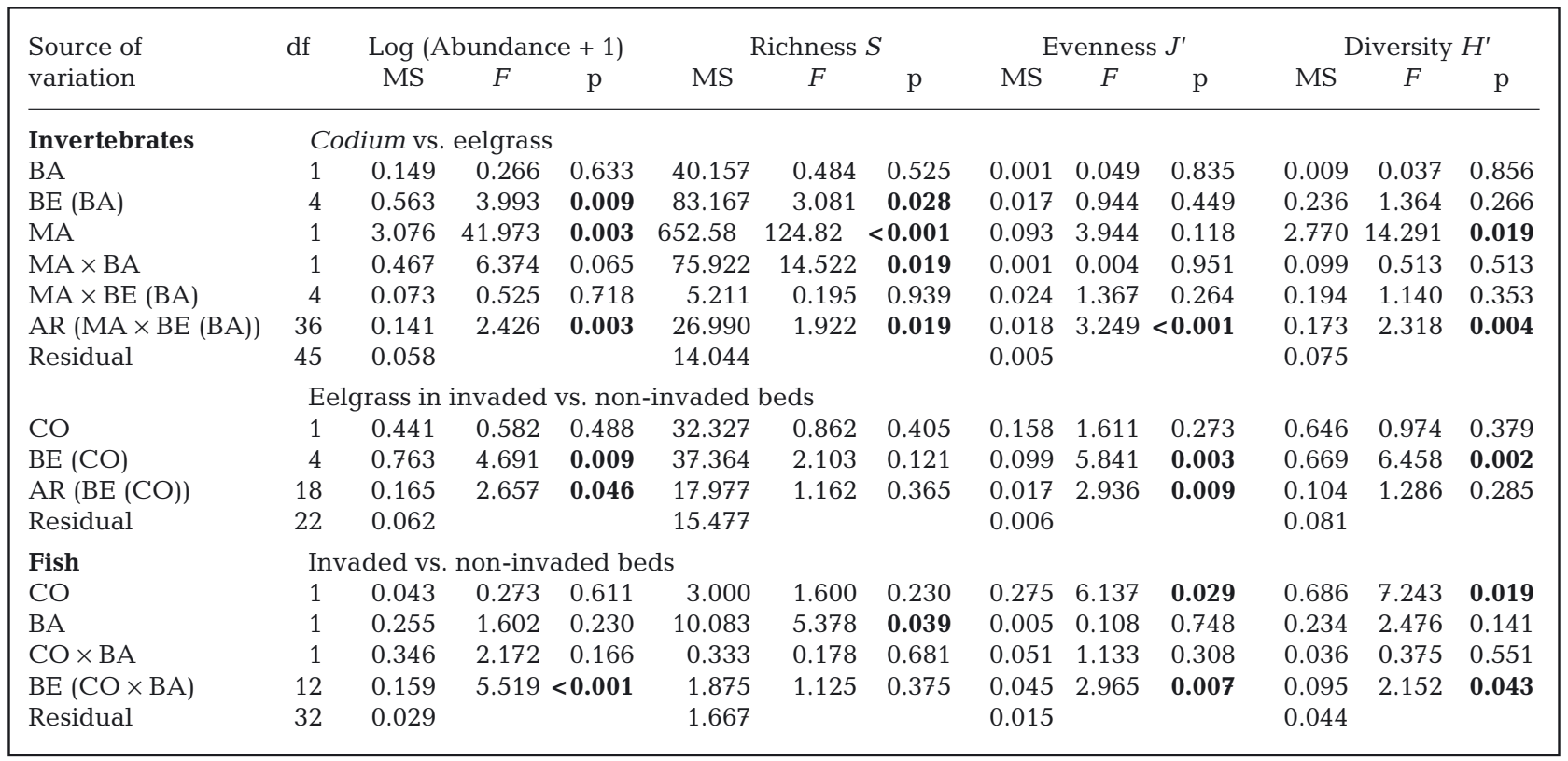
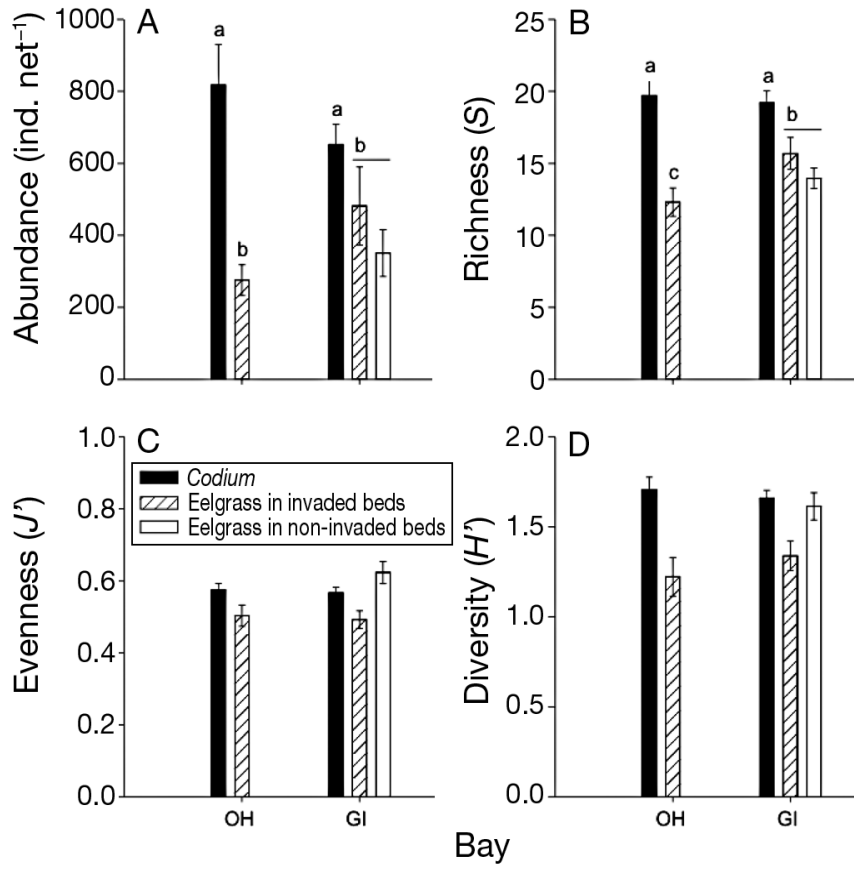

Fig. 2. (A) Abundance, (B) richness, (C) evenness, and (D) diversity of invertebrate assemblages (mean $\pm \mathrm{SE}$ ) associated with Codium and eelgrass macrophytes in 2 bays, Old Harry $(\mathrm{OH})$ and Grosse-Île (GI). Letters and lines above bars indicate significant differences between Codium and eelgrass samples in invaded beds and eelgrass samples between invaded and non-invaded beds, respectively, using Tukey's test $(\mathrm{p}<0.05)$. Results for the corresponding ANOVAs are given in Table 1. Note that for graphical purposes, raw abundance data are presented
Fig. 2) or multivariate assemblage structure (Table 2). Invertebrate assemblages from eelgrass in noninvaded beds were similar to those from invaded beds and both of these were dissimilar to Codium samples (Fig. 3). Assemblage structure was more variable in non-invaded beds relative to that in invaded beds as indicated by the relatively greater spread of symbols representing samples in the corresponding MDS plot (Fig. 3).

Although the polychaetes were the most taxonomically diverse group, no members of this class contributed greatly to the dissimilarity in invertebrate species assemblages between macrophyte types, probably because of the numerical dominance of gastropods. However, as polychaetes are mainly associated with detritus under the macrophytes, they may be relevant to effects occurring at this level and thus were examined separately. Distinct polychaete community structures were observed between Codium and eelgrass samples, but not between eelgrass samples from invaded and non-invaded beds, similar to the patterns for the entire invertebrate community (Table 2). Similarly, MDS shows a consistent pattern of differences between Codium and eelgrass samples within the same beds (Fig. 3). Five species accounted for greater than $75 \%$ of the dissimilarity between polychaete assemblage structures (Table 3) and were all more abundant when associated with Codium than with eelgrass $(\log$ (Harmothoe imbricata +1$) F_{1,4}=22.23, \mathrm{p}=$ 0.009; $\log$ (Polycirrus sp. + 1) $F_{1,4}=19.14, \mathrm{p}=0.012 ; \log$ 
Table 2. PERMANOVA results for the influence of macrophyte type (MA: Codium or eelgrass) or bed composition (CO: invaded or non-invaded) on invertebrate and fish assemblage characteristics in multiple areas (AR), beds (BE), and/or bays (BA). MA, CO and BA are fixed factors. Multivariate analyses were based on Bray-Curtis similarity matrices created using $\sqrt{ }$-transformed abundance data. Values in bold indicate statistically significant effects

\begin{tabular}{|c|c|c|c|c|c|c|c|}
\hline Sources of variation & df & MS & Pseudo- $F$ & $\mathrm{p}($ perm $)$ & MS & Pseudo- $F$ & $\mathrm{p}($ perm $)$ \\
\hline \multicolumn{2}{|l|}{ Codium vs. eelgrass } & \multicolumn{3}{|c|}{ All invertebrates } & \multicolumn{3}{|c|}{ Polychaetes } \\
\hline $\mathrm{BA}$ & 1 & 4653.5 & 0.83 & 0.546 & 2712.2 & 0.71 & 0.677 \\
\hline $\mathrm{BE}(\mathrm{BA})$ & 4 & 5596.6 & 5.38 & 0.001 & 3804.5 & 2.23 & 0.011 \\
\hline $\mathrm{MA}$ & 1 & 14342.0 & 11.58 & 0.006 & 23633.0 & 22.49 & 0.005 \\
\hline $\mathrm{MA} \times \mathrm{BA}$ & 1 & 2029.4 & 1.64 & 0.198 & 994.5 & 0.95 & 0.456 \\
\hline $\mathrm{MA} \times \mathrm{BE}(\mathrm{BA})$ & 4 & 1239.6 & 1.19 & 0.22 & 1050.8 & 0.62 & 0.877 \\
\hline $\mathrm{AR}(\mathrm{MA} \times \mathrm{BE}(\mathrm{BA}))$ & 36 & 1052 & 1.87 & 0.001 & 1723.7 & 1.66 & 0.001 \\
\hline Residual & 45 & 562.8 & & & 1041.5 & & \\
\hline \multicolumn{2}{|c|}{ Eelgrass in invaded vs. non-invaded beds } & \multicolumn{3}{|c|}{ All invertebrates } & \multicolumn{3}{|c|}{ Polychaetes } \\
\hline $\mathrm{CO}$ & 1 & 2335.8 & 0.39 & 0.831 & 1605 & 0.64 & 0.707 \\
\hline $\mathrm{BE}(\mathrm{CO})$ & 4 & 5987.3 & 5.67 & 0.001 & 2512.9 & 1.72 & 0.079 \\
\hline $\mathrm{AR}(\mathrm{BE}(\mathrm{CO}))$ & 18 & 1065.7 & 1.75 & 0.001 & 1474.9 & 1.72 & 0.053 \\
\hline Residual & 22 & 609.2 & & & 943.9 & & \\
\hline \multicolumn{3}{|c|}{ Invaded vs. non-invaded beds } & Fish & & & & \\
\hline $\mathrm{CO}$ & 1 & 3614.7 & 3.67 & 0.014 & & & \\
\hline $\mathrm{BA}$ & 1 & 2498 & 2.54 & 0.053 & & & \\
\hline $\mathrm{CO} \times \mathrm{BA}$ & 1 & 1423.8 & 1.45 & 0.241 & & & \\
\hline $\mathrm{BE}(\mathrm{CO} \times \mathrm{BA})$ & 12 & 985.2 & 2.55 & 0.001 & & & \\
\hline Residual & 32 & 385.8 & & & & & \\
\hline
\end{tabular}

(Pholoe minuta sp. +1$) F_{1,4}=12.84, \mathrm{p}=0.023 ; \log$ (Lepidonotus squamatus +1 ) $F_{1,4}=9.48, \mathrm{p}=0.037$ ), with the exception of Polydora websteri, which had similar abundance in both macrophyte types (log (P. websteri + 1) $\left.F_{1,4}=4.24, \mathrm{p}=0.109\right)$.

\section{Fish assemblages}

Eleven species were observed during the sampling period. Fourspine stickleback Apeltes quadracus, threespine stickleback Gasterosteus aculeatus and blackspotted stickleback Gasterosteus wheatlandi were abundant. Atlantic silverside Menidia menidia, ninespine stickleback Pungitius pungitius and cunner Tautogolabrus adspersus were common, while American sand lance Ammodytes americanus, blue antimora Antimora rostrata, Atlantic herring Clupea harengus harengus, grubby Myoxocephalus aenaeus, and winter flounder Pseudopleuronectes americanus were less common.

Total fish abundance varied between beds without any consistent pattern with respect to invaded or noninvaded beds or bays (Table 1, Fig. 4). Overall, richness was greater in $\mathrm{OH}$ than $\mathrm{GI}$, and both $J^{\prime}$ and $H^{\prime}$ were greater in invaded than in non-invaded beds (Table 1). Of the 6 main fish species, the abundance of only two differed significantly between invaded and non-invaded beds, with both Apeltes quadracus and
Tautogolabrus adspersus being more abundant in beds with Codium (log (A. quadracus + 1) $F_{1,12}=7.10$, $\mathrm{p}=0.021 ; \log (T$. adspersus +1$\left.) F_{1,12}=22.28, \mathrm{p}<0.001\right)$. Variation in the length of fish species did not show any consistent pattern with respect to invaded and noninvaded beds.

Fish assemblage structure differed between invaded and non-invaded beds and was marginally different between bays (Table 2, Fig. 3). Five species accounted for $84 \%$ of the total dissimilarity in assemblage structure between invaded and non-invaded beds (Table 3). On average, however, the dissimilarity in fish assemblage structure between the 2 types of bed was quite low $(37 \%)$, thus explaining the overlap between bed types as seen in the corresponding MDS plot (Fig. 3).

\section{Algal characteristics}

Both abundance and $S$ of invertebrates were positively correlated with Codium biomass and length (Fig. 5), although for a given length of Codium, both indices were greater in the Codium-dominated bed than in the eelgrass-dominated bed (ANCOVA with beds; total abundance $F_{1,39}=7.85, \mathrm{p}=0.008$; richness $\left.F_{1,39}=5.25, \mathrm{p}=0.028\right)$. Codium biomass was the best predictor of both invertebrate abundance and $S$ (Fig. 5). Invertebrate abundance and $S$ were not a 

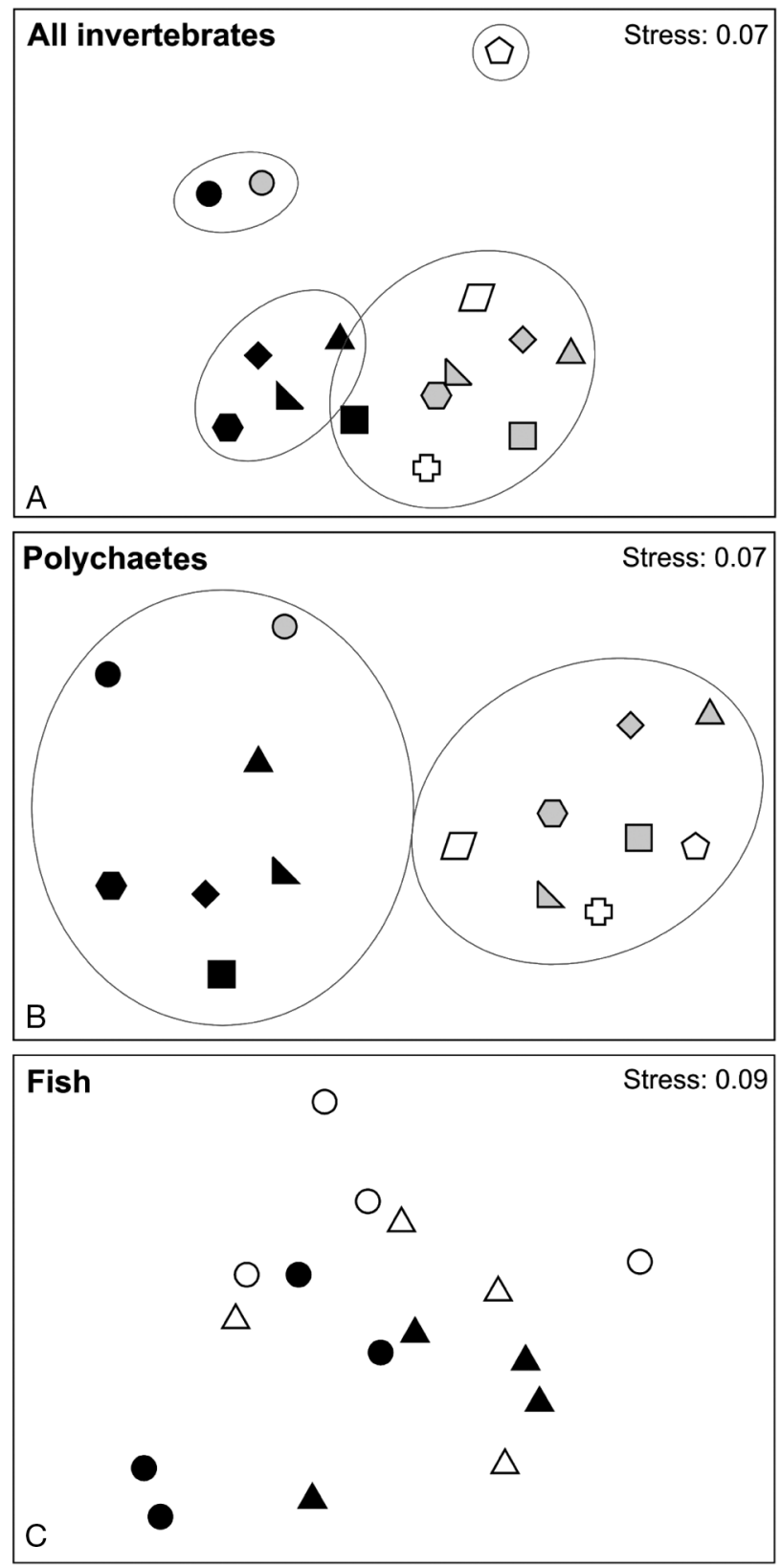

Fig. 3. Non-metric multi-dimensional scaling (MDS) illustrating variation in assemblage structure for (A) all invertebrates, (B) polychaetes only, and (C) fish ( $V$-transformed) among Codium (black), eelgrass in invaded beds (grey), and eelgrass in non-invaded beds (white). Each of the 9 sampled beds is illustrated by different symbols: triangle, diamond, and hexagon represent beds from Old Harry; other symbols are from Grosse-Île. Superimposed clusters represent similarity level of $30 \%$. Results for the corresponding PERMANOVA are given in Table 2

function of bushiness (Fig. 5). The relationships between both abundance or $S$ and all indices of Codium size were also not a function of the interaction between sampled bed and Codium size (data not shown).

\section{Algal manipulations}

The abundance of invertebrates in total and of gastropods (the dominant species group) alone did not differ between Codium with branched and straight fronds at either sampling time (Fig. 6). Invertebrate abundance associated with manipulated thalli was similar to that observed on unmanipulated Codium at the same sampling time (Fig. 6). In contrast, the number of individuals per surface area was significantly lower on eelgrass leaves at the second relative to the first sampling date (Fig. 6). Epifaunal assemblages differed significantly among the manipulated and the natural Codium thalli and eelgrass shoots at either sampling times (August $F_{3,16}=3.45$, $\mathrm{p}($ perm $)=0.001$; October $F_{1,15}=6.50, \mathrm{p}($ perm $\left.)=0.004\right) . A$ posteriori pair-wise comparisons of each treatment level at either sampling time revealed that community structure was similar between branched, straight and natural Codium, but significantly different from eelgrass samples, mainly due to a higher abundance of gastropods and Corophium sp. on Codium fronds (SIMPER).

\section{DISCUSSION}

The present study shows that Codium supports different epibiont assemblages than the native eelgrass and influences the distribution of more mobile species. For epifaunal and fish assemblages, samples associated with Codium were generally characterized by a greater abundance and richness. All taxa observed in the present study were recorded on both macrophyte species, indicating that the invertebrates sampled are generalists and do not require particular habitatforming species. This low specificity for native species has also been observed in other studies that have compared assemblages between native and introduced macrophytes (Viejo 1999, Wernberg et al. 2004, Polte \& Buschbaum 2008). The invertebrate assemblages associated with macrophytes varied at certain scales (the 2 smaller ones-Areas and Beds), but patterns with respect to macrophyte identity (i.e. Codium versus eelgrass samples) were consistent across all levels (i.e. no significant statistical interactions), suggesting that the direct influence of Codium is quite general and robust in the studied area. Moreover, we observed no pattern of invertebrate community characteristics and assemblages in the neighborhood of Codium (eelgrass samples in invaded vs. non-invaded beds).

With no pre-invasion data on faunal communities available for the studied eelgrass system, it is difficult to demonstrate that the appearance of Codium has brought about the observed changes (Didham et al. 2005). Also, as highlighted by Wernberg et al. (2004), our observations cannot exclude the possibility that large spill-over 
Table 3. SIMPER analysis showing the mean abundance of invertebrate species (number sample ${ }^{-1}$ ) and fish (number haul ${ }^{-1}$ ) for replicates of Codium (C) and eelgrass (E), the proportional (\%) and cumulative contribution (Cum\%) of the 5 species that contributed the most to the average dissimilarity (AD) among macrophyte types or bed composition. Data were $\sqrt{ }$-transformed

\begin{tabular}{|c|c|c|c|c|}
\hline Species & $\mathrm{C}$ & $\mathrm{E}$ & $\%$ & Cum\% \\
\hline All invertebrates & \multicolumn{3}{|c|}{$\mathrm{AD}=50.72$} & \\
\hline Onoba aculeus ${ }^{\mathrm{a}}$ & 156 & 37.7 & 14.54 & 14.54 \\
\hline Littorina saxatilis ${ }^{\mathrm{b}}$ & 161.29 & 124.1 & 12.84 & 27.38 \\
\hline Alvania sp. ${ }^{\mathrm{a}}$ & 82.08 & 11.63 & 10.1 & 37.48 \\
\hline Corophium sp. ${ }^{a}$ & 80.1 & 29.7 & 8.71 & 46.19 \\
\hline Hydrobia sp. ${ }^{\mathrm{a}}$ & 11.49 & 2.31 & 4.66 & 50.85 \\
\hline Polychaetes & \multicolumn{3}{|c|}{$\mathrm{AD}=74.94$} & \\
\hline Harmothoe imbricata ${ }^{\mathrm{a}}$ & 10.05 & 2.16 & 32.79 & 32.79 \\
\hline Polycirrus sp. ${ }^{\mathrm{a}}$ & 3.46 & 0.29 & 19.64 & 52.43 \\
\hline Pholoe minuta $^{\mathrm{a}}$ & 1.23 & 0.11 & 11.84 & 64.27 \\
\hline Polydora websteri ${ }^{\mathrm{b}}$ & 0.49 & 0.1 & 8.97 & 72.23 \\
\hline Lepidonotus squamatus ${ }^{\mathrm{a}}$ & 0.16 & 0 & 4.09 & 77.32 \\
\hline Fish & \multicolumn{3}{|c|}{$\mathrm{AD}=36.45$} & \\
\hline Gasterosteus aculeatus $^{\mathrm{b}}$ & 33.76 & 51.7 & 31.14 & 31.14 \\
\hline Apeltes quadracus ${ }^{\mathrm{a}}$ & 15.84 & 7.95 & 16.98 & 48.12 \\
\hline Menidia menidia ${ }^{\mathrm{b}}$ & 1.06 & 1.42 & 13.25 & 61.37 \\
\hline Pungitius pungitius ${ }^{\mathrm{b}}$ & 0.48 & 1.39 & 11.43 & 72.8 \\
\hline Tautogolabrus adspersus ${ }^{\mathrm{a}}$ & 1.25 & 0.02 & 11.19 & 84 \\
\hline
\end{tabular}
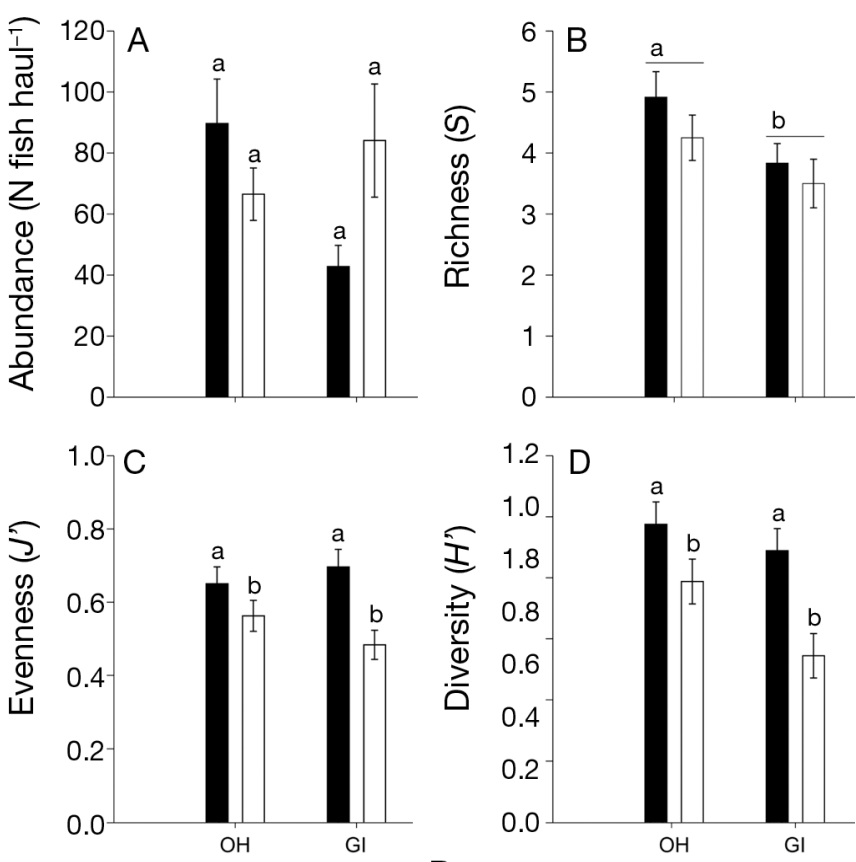

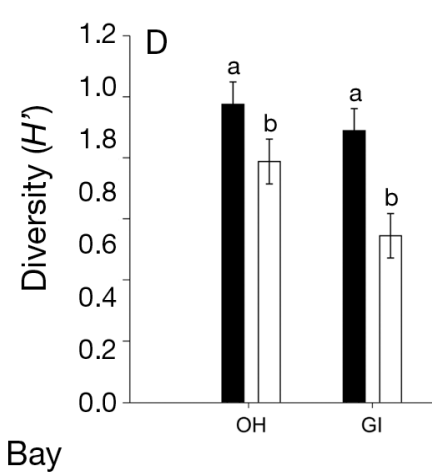

Fig. 4. (A) Abundance, (B) richness, (C) evenness, and (D) diversity of the fish assemblages (mean $\pm \mathrm{SE}$ ) from invaded (black) and non-invaded beds (white) in the 2 studied bays, Old Harry $(\mathrm{OH})$ and Grosse-Île (GI). Results for the corresponding ANOVAs are given in Table 1. Letters and lines above bars indicate significant differences between groups, using Tukey's test $(\mathrm{p}<0.05)$

effects have occurred with the invasion, but they do demonstrate how invasion by Codium affects the existing communities. However, we believe that the possibility that this invasion has caused a great spill-over effect on the structure of the entire community is low, given that no large-scale processes, such as increased loads of diseases or parasites or release of toxins over large areas, are known for this species. Temporal variation was not examined in the present study and the consistency of the observed patterns through time is thus unknown. Inter-annual and seasonal variation in Codium biomass and temporal variation in the abundance of epifaunal species may both influence species assemblages associated with Codium.

\section{Invertebrate assemblages}

The association of a greater abundance and number of invertebrate species with more structurally complex macrophytes, in this case Codium, has also been observed in other studies on algae and seagrass (Heck \& Wetstone 1977, Dean \& Connell 1987b, Bates \& DeWreede 2007), and may be caused by a number of physical and/or biological mechanisms. The simplest physical explanation is that differences are due to sampling artefacts whereby the greater surface area associated with Codium fronds increases the total number of invertebrates sampled and the chance of sampling more rare species, as has been demonstrated in kelp forests for mobile macrofauna (Norderhaug et al. 2007). Codium morphology can further modify the physical environment by reducing light availability for epibenthos and ambient flow rates, thus increasing sedimentation relative to that in eelgrass. The trapping of sediments and organic matter, as well as the interception of planktonic larvae by algal and other canopies has been shown to influence community structure (Harvey et al. 1995, Kelaher et al. 2001, Harries et al. 2007). This may explain the greater abundance of surface deposit feeders, such Corophium sp., Polycirrus sp. and other polychaetes that were observed to be associated with Codium in the present study.

Dichotomous branch morphology and the more compact habitat of Codium thalli may provide better shelter for prey by reducing predation pressure through habitat selection or reduced predator efficiency (Dean \& Connell 1987c). Invertebrate assemblages may also differ because the 2 macrophyte types differ with respect 

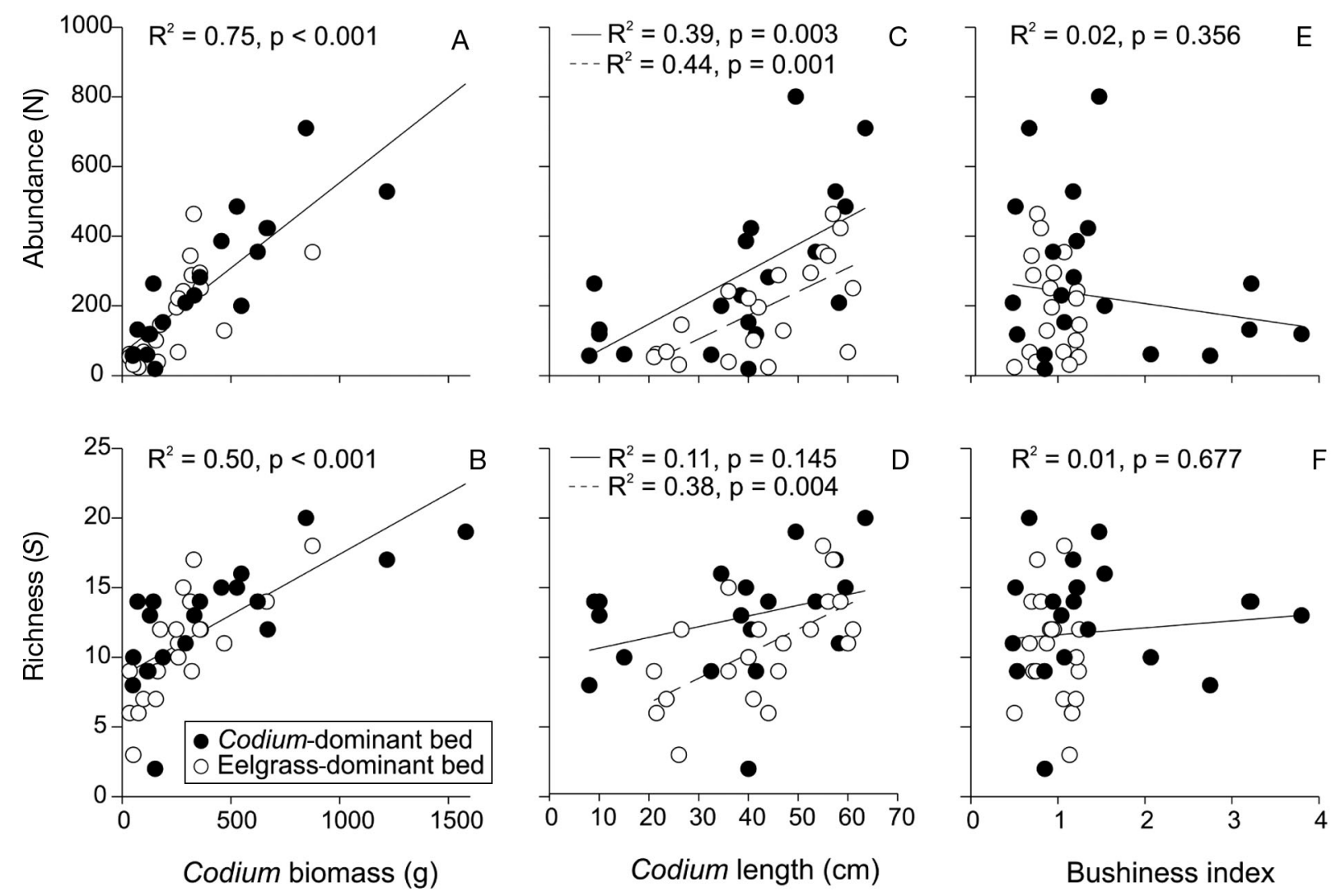

Fig. 5. Relationships associated with thalli from a bed where Codium was the dominant canopy and a bed where eelgrass was the dominant canopy. (A) Codium biomass and species abundance, (B) Codium biomass and species richness, (C) Codium length and species abundance, (D) Codium length and species richness, (E) bushiness index and species abundance, and (F) bushiness index and species richness

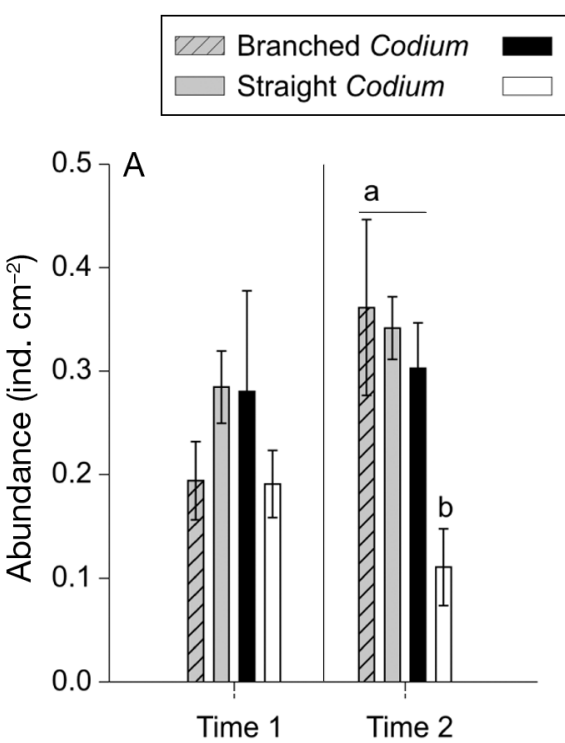

\section{Unmanipulated eelgrass}

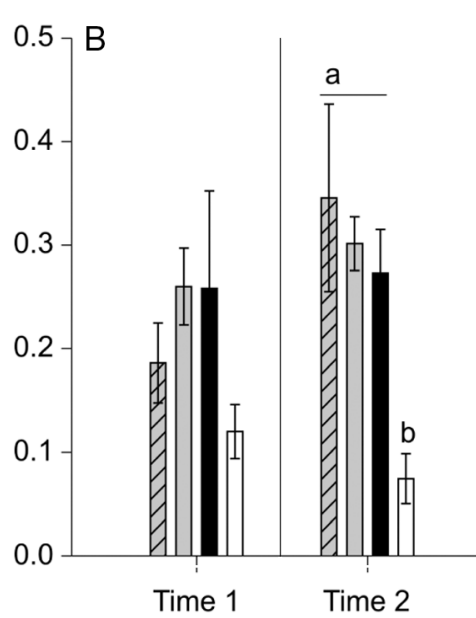

Fig. 6. Abundances associated with manipulated Codium having different thallus architecture (Branched and Straight), unmanipulated Codium, and unmanipulated eelgrass canopies (A) for all invertebrates (mean \pm SE) and (B) of only the gastropods (mean $\pm \mathrm{SE}$ ). Letters and lines above bars indicate significant differences between groups, using Tukey's test $(p<0.05)$

to trophic structure. The majority of species that contributed most to the dissimilarity in community structure between macrophyte species feed on epiphytes rather than directly on the macrophytes. Codium morphology may facilitate the accumulation of epiphytes and diatoms as its branching and hairy texture may favour colonization by epiphytes (Seed \& O'Connor 1981). However, as concluded by Dean \& Connell (1987a), complexity and the number of epiphytes both vary with macrophyte biomass, and thus all the above-mentioned mechanisms may contribute to the observed differences between Codium and eelgrass.

\section{Fish assemblages}

Much as for invertebrates, shelter (e.g. Gotceitas et al. 1997) and food (e.g. Connolly 1994) are cited as factors influ- 
ences the association of fish with different macrophytes, and these mechanisms may explain the greater abundance of fourspine stickleback Apeltes quadracus and juvenile cunner Tautogolabrus adspersus in beds with Codium. The clear association of these species with Codium is evidence of the distinct differences in the type of habitat that Codium and eelgrass provide. Similarly, Levin et al. (2002) also found that recruitment of $T$. adspersus differed between Codium and native kelp, although it was greater for kelp - a typical cunner habitat - than for Codium. This contrast in the results highlights how the effects of an invasive alga on a given species may depend on prior use of the original habitat by that species.

\section{Algal characteristics}

Codium biomass was the best predictor of epifaunal abundance and richness, a correlation also observed for eelgrass (Heck \& Wetstone 1977, Attrill et al. 2000). Within a given macrophyte species, biomass is closely related to surface area, and thus this measure is a good proxy for the area available for colonization. Conversely, the bushiness index, a proxy for complexity, was not a good predictor of invertebrate abundance and richness in the present study. This measure of algal morphology did not vary greatly among sampled thalli as the entire range of bushiness was not represented in the meadow with low algal density. Thus it may be premature to conclude that Codium bushiness does not influence associated invertebrate abundance and richness in eelgrass beds.

The difference in length-dependent relationships between the Codium-dominant site and the eelgrassdominant site (Fig. 5) suggests that local conditions influence the association of invertebrates with Codium. In this case, the proximity to other Codium may have influenced the abundance and richness of invertebrates associated with Codium itself. Codium was not as long as eelgrass, which may decrease the capture of invertebrates by Codium thalli when they are surrounded by taller macrophytes. This conjecture is in contrast to the results for the invertebrate assemblages associated with eelgrass samples (see 'Invertebrate assemblages' section above) which did not differ between invaded and non-invaded beds.

\section{Algal manipulations}

Although biomass may be a good estimator of colonizable surface area, variation in abundance and richness may also be a function of structural complexity, which can also vary with biomass (Dean \& Connell 1987a). Results from the manipulative experiment indicated that structural complexity, defined as branching complexity, did not influence the total abundance and species assemblages of epifauna associated with Codium thalli. As the perception of 'complexity' may depend on an organism's size (Gee \& Warwick 1994, Attrill et al. 2000), the invertebrates associated with Codium may respond more to complexity occurring at finer spatial scales (e.g. epiphytes, surface hairs) than to factors such as branching structure. Biotic mechanisms, such as trophic structure and predation pressure, may be more important in explaining the relationship between epifauna and Codium. Greater colonization by diatoms or other epiphytes on manipulated algae over 9 wk may have attracted greater numbers of gastropods.

\section{Ecological implications}

Overall, we found no evidence that Codium in eelgrass beds had a negative impact on eelgrassassociated invertebrate or fish populations. Indeed, in all cases, any differences observed were due to increased standing stocks of certain species in areas with Codium. The present study thus adds further empirical evidence that algal invasions may have relatively low impacts on native faunal assemblages (Thomsen et al. 2009). However, future changes in biotic or environmental conditions in the invaded community due to increased numbers or types of invading species or human activities could interact and create long-term effects of Codium invasion that differ from those shortterm effects observed in the present study (see Grosholz 2005). Also, the assessment of impacts of invasion by a habitat-forming species may depend on to what extent the structure and function of the invaded communities varies from the indigenous state. For example, the invasion by the rhizophytic green alga Caulerpa taxifolia in Australia occurred in a previously unvegetated habitat, which increased local epifaunal diversity (Gribben et al. 2009) with concomitant detrimental effects on infaunal assemblages (McKinnon et al. 2009). Contrary to the change in macrophyte composition that we observed, this invasion created an entirely new vegetated community that was much different from the original unvegetated habitat in terms of both structure and function.

In contrast to other studies reporting the effects of invasive alga in soft-bottom habitats (e.g. den Hartog 1997, McKinnon et al. 2009), Codium in our study sites depends on the presence of eelgrass for its establishment and likely its persistence. Currently, the preemptive or competitive ability of Codium in the studied meadows has still not been clarified, although lower 
eelgrass density has been observed where Codium reaches high biomass (A. Drouin unpubl. data). Low eelgrass density may facilitate settlement of Codium on rhizomes, but algal cover may in turn reduce eelgrass growth (Hauxwell et al. 2001) and regeneration (den Hartog 1997). If Codium competes with eelgrass or mats of drift alga influence eelgrass productivity or survival, this could influence habitat dynamics and ultimately decrease macrophyte cover in the area (but see Thomsen \& McGlathery 2007). The severity of the impact of Codium on communities in seagrass habitat may depend then on the spatio-temporal interaction between these 2 habitats. Future studies should focus on these aspects to better assess the longer-term impact of this invasion.

Acknowledgements. We thank B. Clynick, N. Simard, P. Archambault, M. Roy-Latreille, M. Huot and R. Belley for help with field work, M. Couture-Plante, M. Morin and K. Richer for work in the lab, and A. Weise for help with illustrations. This work was supported by the Fisheries and Oceans Canada, and doctoral scholarships to A.D. by the Fonds québécois de la recherche sur la nature et les technologies (FQRNT), Québec-Océan, and the Southern Gulf of St. Lawrence Coalition on Sustainability.

\section{LITERATURE CITED}

Anderson MJ (2001) A new method for non-parametric multivariate analysis of variance. Austral Ecol 26:32-46

Attrill MJ, Strong JA, Rowden AA (2000) Are macroinvertebrate communities influenced by seagrass structural complexity? Ecography 23:114-121

> Bates CR, DeWreede RE (2007) Do changes in seaweed biodiversity influence associated invertebrate epifauna? J Exp Mar Biol Ecol 344:206-214

Bégin C, Scheibling RE (2003) Growth and survival of the invasive green alga Codium fragile ssp. tomentosoides in tide pools on rocky shore in Nova Scotia. Bot Mar 46: 404-412

Bégin C, Johnson LE, Himmelman JH (2004) Macroalgal canopies: distribution and diversity of associated invertebrates and effects on the recruitment and growth of mussels. Mar Ecol Prog Ser 271:121-132

Bruno JF, Stachowicz JJ, Bertness MD (2003) Inclusion of facilitation into ecological theory. Trends Ecol Evol 18: 119-125

Chavanich S, Harris LG (2004) Impact of the non-native macroalga Codium fragile (Sur.) Hariot ssp. tomentosoides (van Goor) Silva on the native snail Lacuna vincta (Montagu, 1803) in the Gulf of Maine. Veliger 47:85-90

> Christie H, Jorgensen NM, Norderhaug KM (2007) Bushy or smooth, high or low; importance of habitat architecture and vertical position for the distribution of the fauna on kelp. J Sea Res 58:198-208

$>$ Clarke KR (1993) Non-parametric multivariate analyses of changes in community structure. Aust J Ecol 18:117-143

Clarke KR, Warwick RM (2001) Change in marine communities: an approach to statistical analysis and interpretation, 2nd edition. Plymouth Marine Laboratory, Plymouth

> Connolly RM (1994) Removal of seagrass canopy: effects on small fish and their prey. J Exp Mar Biol Ecol 184:99-110
Crooks JA (2002) Characterizing ecosystem-level consequences of biological invasions: the role of ecosystem engineers. Oikos 97:153-166

> Dean RL, Connell JH (1987a) Marine invertebrates in an algal succession. III. Mechanisms linking habitat complexity with diversity. J Exp Mar Biol Ecol 109:249-273

> Dean RL, Connell JH (1987b) Marine invertebrates in an algal succession. I. Variations in abundance and diversity with succession. J Exp Mar Biol Ecol 109:195-215

Dean RL, Connell JH (1987c) Marine invertebrates in an algal succession. II. Tests of hypotheses to explain changes in diversity with succession. J Exp Mar Biol Ecol 109: $217-247$

> den Hartog C (1997) Is Sargassum muticum a threat to eelgrass beds? Aquat Bot 58:37-41

> Didham RK, Tylianakis JM, Hutchison MA, Ewers RM, Gemmell NJ (2005) Are invasive species the drivers of ecological change? Trends Ecol Evol 20:470-474

- Garbary DJ, Fraser SJ, Hubbard C, Kim KY (2004) Codium fragile: rhizomatous growth in the Zostera thief of eastern Canada. Helgol Mar Res 58:141-146

Gee JM, Warwick RM (1994) Body-size distribution in a marine metazoan community and the fractal dimensions of macroalgae. J Exp Mar Biol Ecol 178:247-259

Gotceitas V, Fraser S, Brown JA (1997) Use of eelgrass beds (Zostera marina) by juvenile Atlantic cod (Gadus morhua). Can J Fish Aquat Sci 54:1306-1319

Gribben PE, Byers JE, Clements M, McKenzie LA, Steinberg PD, Wright JT (2009) Behavioural interactions between ecosystem engineers control community species richness. Ecol Lett 12:1127-1136

Grosholz ED (2005) Recent biological invasion may hasten invasional meltdown by accelerating historical introductions. Proc Natl Acad Sci USA 102:1088-1091

Harries DB, Harrow S, Wilson JR, Mair JM, Donnan DW (2007) The establishment of the invasive alga Sargassum muticum on the west coast of Scotland: a preliminary assessment of community effects. J Mar Biol Assoc UK 87: $1057-1067$

Harris LG, Jones AC (2005) Temperature, herbivory and epibiont acquisitions as factors controlling the distribution and ecological role of an invasive seaweed. Biol Invasions 7:913-924

> Harvey M, Bourget E, Ingram RG (1995) Experimental evidence of passive accumulation of marine bivalve larvae on filamentous epibenthic structures. Limnol Oceanogr 40: 94-104

Hauxwell J, Cebrian J, Furlong C, Valiela I (2001) Macroalgal canopies contribute to eelgrass (Zostera marina) decline in temperate estuarine ecosystems. Ecology 82:1007-1022

Heck KLJ, Wetstone GS (1977) Habitat complexity and invertebrate species richness and abundance in tropical seagrass meadows. J Biogeogr 4:135-142

Kelaher BP, Chapman MG, Underwood AJ (2001) Spatial patterns of diverse macrofaunal assemblages in coralline turf and their associations with environmental variables. J Mar Biol Assoc UK 81:917-930

Levin PS, Coyer JA, Petrik R, Good TP (2002) Communitywide effects of nonindigenous species on temperate rocky reefs. Ecology 83:3182-3193

> Lotze HK, Lenihan HS, Bourque BJ, Bradbury RH (2006) Depletion, degradation, and recovery potential of estuaries and coastal seas. Science 312:1806-1809

> Lyons DA, Scheibling RE (2007) Effect of dietary history and algal traits on feeding rate and food preference in the green sea urchin Strongylocentrotus droebachiensis. J Exp Mar Biol Ecol 349:194-204 
Lyons DA, Scheibling RE (2009) Range expansion by invasive marine algae: rates and pattern of spread at a regional scale. Divers Distrib 15:762-775

Malinowski KC, Ramus J (1973) Growth of the green alga Codium fragile in a Connecticut estuary. J Phycol 9: 102-110

McArdle BH, Anderson MJ (2001) Fitting multivariate models to community data: a comment on distance-based redundancy analysis. Ecology 82:290-297

McKinnon JG, Gribben PE, Davis AR, Jolley DF, Wright JT (2009) Differences in soft-sediment macrobenthic assemblages invaded by Caulerpa taxifolia compared to uninvaded habitats. Mar Ecol Prog Ser 380:59-71

Norderhaug KM, Christie H, Fredriksen S (2007) Is habitat size an important factor for faunal abundances on kelp (Laminaria hyperborea)? J Sea Res 58:120-124

Nordström M, Booth DM (2007) Drift algae reduce foraging efficiency of juvenile flatfish. J Sea Res 58:335-341

Polte P, Buschbaum C (2008) Native pipefish Entelurus aequoreus are promoted by the introduced seaweed Sargassum muticum in the northern Wadden Sea, North Sea. Aquat Biol 3:11-18

Provan J, Booth D, Todd NP, Beatty GE, Maggs CA (2008) Tracking biological invasions in space and time: elucidating the invasive history of the green alga Codium fragile using old DNA. Divers Distrib 14:343-354

Quinn GP, Keough MJ (2002) Experimental design and data analysis for biologists. Cambridge University Press, Cambridge

Schaffelke B, Hewitt CL (2007) Impacts of introduced seaweeds. Bot Mar 50:397-417

Scheibling RE, Gagnon P (2006) Competitive interactions between the invasive green alga Codium fragile ssp. tomentosoides and native canopy-forming seaweeds in NovaScotia (Canada). Mar Ecol Prog Ser 325:1-14

Schmidt AL, Scheibling RE (2006) A comparison of epifauna and epiphytes on native kelps (Laminaria species) and invasive alga (Codium fragile ssp. tomentosoides) in Nova Scotia, Canada. Bot Mar 49:315-330

Schmidt AL, Scheibling RE (2007) Effects of native and invasive macroalgal canopies on composition and abundance of mobile benthic macrofauna and turf-forming algae. J Exp Mar Biol Ecol 341:110-130

Editorial responsibility: Kenneth Heck, Dauphin Island, Alabama, USA
Seed R, O'Connor RJ (1981) Community organization in marine algal epifaunas. Annu Rev Ecol Syst 12:49-74

Simard N, Paille N, McKindsey CW (2007) Codium fragile ssp. tomentosoides: revue de littérature et situation aux Îles-de-la-Madeleine. Rapport manuscrit canadien des sciences halieutiques et aquatiques 2786:vii+40p

> Thomsen MS, McGlathery KJ (2007) Stress tolerance of the invasive macroalgae Codium fragile and Gracilaria vermiculophylla in a soft-bottom turbid lagoon. Biol Invasions 9:499-513

> Thomsen MS, Wernberg T, Tuya F, Silliman BR (2009) Evidence for impacts of nonindigenous macroalgae: a metaanalysis of experimental field studies. J Phycol 45:812-819

Trowbridge CD (1998) Ecology of the green macroalga Codium fragile (Surringar) Harriot 1889: invasive and non-invasive subspecies. Oceanogr Mar Biol Annu Rev 36: $1-64$

Underwood AJ (1981) Techniques of analysis of variance in experimental marine biology and ecology. Oceanogr Mar Biol Annu Rev 19:513-605

> Viejo RM (1999) Mobile epifauna inhabiting the invasive Sargassum muticum and two local seaweeds in the northern Spain. Aquat Bot 64:131-149

Wernberg T, Thomsen MS, Staehr PA, Pedersen MF (2000) Comparative phenology of Sargassum muticum and Halidrys siliquosa (Phaeophyceae: Fucales) in Limfjorden, Denmark. Bot Mar 43:31-39

> Wernberg T, Thomsen MS, Staehr PA, Pedersen MF (2004) Epibiota communities of the introduced and indigenous macroalgal relatives Sargassum muticum and Halidrys siliquosa in Limfjorden (Denmark). Helgol Mar Res 58: $154-161$

Williams SL, Grosholz ED (2008) The invasive species challenge in the estuarine and coastal environments: marrying management and science. Estuar Coast 31:3-20

- Williams SL, Smith JE (2007) A global review of the distribution, taxonomy, and impacts of introduced seaweeds. Annu Rev Ecol Syst 38:327-359

> York PH, Booth DJ, Glasby TM, Pease BC (2006) Fish assemblages in habitats dominated by Caulerpa taxifolia and native seagrasses in south-eastern Australia. Mar Ecol Prog Ser 312:223-234

Submitted: August 10, 2009; Accepted: November 27, 2010 Proofs received from author(s): February 8, 2011 